\title{
Production Efficiency of Wet Rice and Wet Terrace Cultivation in Nagaland: Some Field Based Evidences
}

\author{
B. Imnawapang Longkumer ${ }^{1^{*}}$ and Giribabu, M. ${ }^{2}$ \\ ${ }^{1}$ Department of Economics, Fazl Ali College, Mokokchung-798601, Nagaland \\ ${ }^{2}$ Department of Economics, Lumami- 798627, Nagaland University, Nagaland \\ *Correspondence author: nasapri23@gmail.com
}

\begin{abstract}
Analysis of production efficiency of rice cultivation of Wet Rice Cultivation (WRC) in Dimapur and Wet Terrace Cultivation (WTC) in Phek district of the state of Nagaland revealed that, WRC under Dimapur district experienced the highest productivity than WTC under Phek district. The reason for higher productivity for WRC when compared to WTC is due to the better use of seeds, fertilizer, machines, and availability of irrigation facility which had a great impact on production and productivity. Both the farming systems in the two districts are labour intensive and the average labour absorption per acre in Phek district is 41.57 labour man days whereas, in Dimapur district it is about 43.9 labour man days. Result from Cobb-Douglas production function shows that capital plays the predominant role in production in both the districts. The study is based on primary data and the data was collected from 300 household from the two districts and three villages each district using a pre-tested interview schedule. The period of the study was the crop year of 2016-17. The study was found that the cost of production is high in case of small and medium farmers, while the profit rate was high for marginal farmers showing inverse relation between farm size and profitability.

\section{Highlights}

(o Purposive sample technique

- WTC under Phek and WRC under Dimapur district

( Sample size- 150 household each

(- Comparative analysis

( $\mathrm{WRC}$ is more profitable compared to WTC
\end{abstract}

Keywords: Wet Terrace \& Wet Rice Cultivation, Production function and Efficiency

Agriculture plays an essential role in the process of economic development of a country or a region and also provides food, generates employment, contributes to market of industrial goods and earns income. Agriculture production in India can be increased by a rapid and mass development only by breaking through the state of art and introducing modern technology in a package, consisting of new inputs, agricultural education, special skills, technique and competent guidance in farm planning (Venkatareddy Chennareddy, 1967). Agricultural strategy for raising productivity must be technical change, that is both seed and complementary farm inputs and resources based rather than only seed or only resource-based (Bhupat M. Desai et al. 1999). Agriculture is a dominant activity in Nagaland both in terms of output and employment. In spite of certain favourable conditions prevailing in the state for a prosperous agriculture, productivity of major crops has remained at a low level. The state is an agrarian economy with over $70 \%$ of the population depending on it. Rice is the dominant crop and also the staple diet of the people. Out of the 2,60,000 ha of gross cropped area under food grains, rice accounts for about $84.4 \%$. The productivity of rice per acre in is the state is very low, while the cost of production is very high. Cost escalation is the most important factor, which makes rice cultivation 
CP Longkumer and Giribabu

a relatively less remunerative enterprise and it suggested that mechanization should be adopted wherever possible, which will reduce the labour cost (Mohandas and Thomas, 1997).

There are three methods of cultivation predominantly in Nagaland, i,e, jhuming and Wet terrace and Wet Rice cultivation. The area under jhum cultivation is about 87.339 hectares and under terraced cultivation is about 62,091 hectares. Jhum cultivation is practiced in all parts of Nagaland, while Wet rice cultivation is confined to the plain areas of Dimapur district, and Wet terrace cultivation is confined to Kohima and Phek districts. Rice production in the state is constrained by bio-physical, economic and technological bottlenecks. Increasing farm size and technology has substantial benefits for efficiency improvement in cultivation of rice and other regional factors were also found to be important in influencing production efficiency (Linh $\mathrm{H}$. Vu, 1994).

Young generation has better ability to adopt modern technology, when compared to old farmers who are technically inefficient therefore, young generation should be motivated to participate in agricultural related activities and to make timely decisions (Abedullah et al. 2007). Suggest the benefits of indigenous practice of Zabo and Alder rice farming system by Naga farmers which is soil and water conserving oriented and is sustainable in the long run(Longshibeni N Kithan, 2014).

Despite of all these obstacles, the farmers have significantly moved on to adopt system such as integrated approaches, organic, dry land farming and double cropping system (Rukuosietuo Kuotsuo et al. 2014). A shift from jhum to scientific and ecologically less harmful forms of cultivation like settled cultivation sound to be more profitable but it is doubtful whether settled cultivation can sustain jhum cultivators looking at the context of the uneconomic size of holdings and agricultural stagnation characteristic of eastern India (K.N. Ninan, 1992).

The study will help us to find out the differences in cost of production and productivity among different farming systems, its technical and economic efficiency and factors that promotes as well as hinders production efficiency among different rice farming villages.

\section{Review of Literature}

Venkatareddy Chennareddy (1967)a rapid and mass development in agriculture production in India can be increased only by breaking through the state of art and introducing modern technology. Similarly,Singh and Nareshkumar (1998) observed that the main reason for efficiency was due to timely transplanting and application of irrigation, fertilizers and pesticides in appropriate dosages and there was a considerable variation in efficiency across regions and size categories. Whereas, Linh H. Vu (1994) states that increasing land holding and farm size has substantial benefits for efficiency improvement in cultivation of rice and regional factors were also found to be important in influencing technical efficiency

Abedullah et al. (2007) old farmers are technically inefficient and therefore, young generation needs to be motivated to participate in agricultural related activities because young generation has better ability to adopt modern technology and to make timely decisions. Rukuosietuo Kuotsuo et al. (2014) scientific systems of organic rice cultivation should be taught to the farmers that can give a better option to generate income in a land where fertilizers have never been used before. Longshibeni N Kithan (2014) suggest the benefits of indigenous practice of Zabo and Alder rice farming system by Naga farmers which is soil and water conserving oriented and is sustainable in the long run.

\section{Data and Methodology}

For the analysis, primary data was used and data was collected during the year 2016-17. All together 300 household from two districts were selected through interview method. Dimapur district for WRC and Phek district for WTC was selected purposively since these two districts have the largest area, production and productivity under WRC/WTC in Nagaland. A pre-tested comprehensive interview schedule was designed for the canvass in the study area. The data has been analyzed using appropriate statistical tools and technique, such as ratios, percentages, proportions. In addition to the above usual statistical measures Cobb Douglas production function and stochastic production frontier models are applied. 


\section{Model}

The multiple regression model may be specified as,

$$
Y_{t}=\sum_{i=0}^{k} \beta_{i} \mathrm{X}_{i t}+\mu_{t}
$$

Where, $Y_{t}$ is the dependent variable, the $X^{\prime}$ 's are the independent variables, and $\mu_{t}$ is the error term. $\beta_{1}$ is the constant term, or intercept of the equation.

\section{Cobb-Douglas production Function is,}

$$
\ln Y_{i}=\beta 0+\sum_{k=1}^{n} \beta_{k} \ln x_{k}+v_{i}-u_{i}
$$

Where, $Y_{i}$ is the output, $\beta$ is constant, $k$ is the quantity of capital, $v_{i}$ and $u_{i}$ are the error terms.

\section{Production and Productivity Distribution}

Table 1 and 2 shows that the distribution production and productivity of rice under different farm size groups in selected districts. Out of 150 households selected from the three villages in Dimapur district, small farmers constitute the largest with a total of 65 (43.335) household, and large farmers are the least with $13(8.66 \%)$ household.

Table 1: Yield under WRC in the three selected under Dimapur district ( $Y=$ Yield/Acre $)$

\begin{tabular}{ccccccc}
\hline \multirow{2}{*}{$\begin{array}{c}\text { Farm } \\
\text { Size }\end{array}$} & \multicolumn{2}{c}{ SINGRIJAN } & \multicolumn{2}{c}{ NIHOTO } & \multicolumn{2}{c}{ NIHOKHU } \\
\cline { 2 - 7 } & $\begin{array}{c}\text { Yield Kg } \\
\text { In Bags }\end{array}$ & $\begin{array}{c}\text { Yield in } \\
\text { Kg }\end{array}$ & Bags & $\begin{array}{c}\text { Yield in } \\
\text { Kg }\end{array}$ & Bags \\
\hline MF & 1598.48 & 21.31 & 1567.02 & 20.89 & 1541.02 & 20.54 \\
SF & 1579.5 & 21.06 & 1575.34 & 21.00 & 1652.3 & 22.03 \\
MDF & 1600.04 & 21.33 & 1558.83 & 20.78 & 1372.28 & 18.29 \\
LF & 1515.8 & 20.2 & 1481.09 & 19.74 & 1101.23 & 14.68 \\
ALL & 1573.45 & 20.97 & 1545.57 & 20.60 & 1416.61 & 18.88 \\
\hline
\end{tabular}

Source: Field survey 2016-17; Note: MF=Marginal farmer, $S F=$ Small farmer, $M D F=$ Medium farmer, $L F=$ Large farmer; Bag is measured as per the standard measurement set by Govt. of India, i.e., $75 \mathrm{Kg}$ per bag.

Singrijan village gets the highest yield per acre of $1573.45 \mathrm{Kg} /$ Acre or 20.97 bags among the three villages and medium farmers with a total of 11 household get the maximum yield per acre of $1600.04 \mathrm{Kg} /$ Acre or 21.33 bags, which is much higher than the average yield of the village. While large farmers are the one with lowest yield per acre of only $1515.8 \mathrm{Kg} /$ Acre. In Nihoto village, small farmers with a total of 19 household gets the maximum yield per acre of $1575.34 \mathrm{Kg}$ /Acre or 21 bags. Whereas large farmers with a total of 6 household gets a yield of only $1481.09 \mathrm{Kg} /$ Acre or 19.74 bags which is the lowest yield per acre in the village. Even in Nihokhu village yield per acre is maximum for small farmers with a total of 18 household getting an average yield of 1652.3 $\mathrm{Kg} /$ Acre. Whereas large farmers with the least household of 6 gets a yield of $1101.23 \mathrm{Kg} /$ Acre or 14.68 bags which is below the average yield of the village of $1416.61 \mathrm{Kg} /$ Acre.

Table 2: Yield under WTC in the three selected

\begin{tabular}{|c|c|c|c|c|c|c|}
\hline \multirow{2}{*}{$\begin{array}{c}\text { Farm } \\
\text { Size }\end{array}$} & \multicolumn{2}{|c|}{ KIKRUMA } & \multicolumn{2}{|c|}{ CHIZAMI } & \multicolumn{2}{|c|}{ PFUTSEROMI } \\
\hline & $\begin{array}{c}\text { Yield in } \\
\mathrm{Kg}\end{array}$ & Bags & $\begin{array}{c}\text { Yield in } \\
\mathrm{Kg}\end{array}$ & Bags & $\begin{array}{c}\text { Yield in } \\
\mathrm{Kg}\end{array}$ & Bags \\
\hline $\mathrm{MF}$ & 1218.49 & 16.24 & 1254.89 & 16.73 & 1183 & 15.77 \\
\hline SF & 1088.49 & 14.51 & 1221.74 & 16.28 & 1229.8 & 16.39 \\
\hline MDF & 1219.14 & 16.25 & 1229.02 & 16.38 & 1175.85 & 15.67 \\
\hline $\mathrm{LF}$ & 1259.44 & 16.79 & 1246.44 & 16.61 & 1222 & 16.29 \\
\hline ALL & 1196.39 & 15.95 & 1237.99 & 16.50 & 1196.13 & 15.94 \\
\hline
\end{tabular}
villages under Phek district (Y=Yield/Acre)

Source: Field survey 2016-17; MF=Marginal farmer, SF=Small farmer, $M D F=$ Medium farmer, LF=Large farmer; Note: Bag is measured as per the standard measurement set by Govt. of India, i,e, $75 \mathrm{Kg}$ per bag.

Similarly, in Phek district medium farmers constitute the maximum number with a total of $62(41.33 \%)$ whereas, large farmers is only $8(5.33 \%)$ households. Chizami village gives the highest yield among the three villages and gets a yield of $1237.99 \mathrm{Kg} /$ Acre or 16.50 bags. In Kikruma village large farmers produces an average of $1259.44 \mathrm{Kg} /$ Acre which is the highest among all the farm size groups in the village followed by medium farmers $1219.14 \mathrm{Kg} /$ Acre and small farmers $1088.49 \mathrm{Kg} /$ Acre. On contrary to that in Chizami village marginal farmers yield highest with an average about $1254.89 \mathrm{Kg} /$ Acre, while small farmers yields lowest about $1221.74 \mathrm{Kg} /$ Acre Whereas in Pfutseromi village, small farmers yields highest among the four farm size with a yield of $1229.8 \mathrm{Kg} /$ Acre and medium farmers are the ones that gets the lowest yield with an average yield of $1175.85 \mathrm{Kg} /$ Acre $^{1}$.

\footnotetext{
${ }^{1}$ Price per bag is sold at different price by different farmers depending on the price the wholesaler is willing to buy but the actual market price is ₹1200 per bag and the measurement is done based on this
} 
CD Longkumer and Giribabu

\section{Cost of Cultivation}

The use of input pattern of rice cultivation by both the farming system is given in the table 3 and 4 . The data indicates that farmers under WRC in Dimapur district use more inputs than their counterparts in Phek district. The use of inputs varies among different farm size and also among different villages. Nihokhu village incurs the highest input cost among the three villages. The use of fertilizers and pesticides, farm yard manures are maximum in Singrijan village with an average of ₹ 739.25 and ₹ 1356.71 per acre. On the other hand, the use of bullock labour and transport is maximum in
Nihokhu village with an average of ₹ 313.80 and ₹ 312.35 respectively and the reason is that most of this input are purchased at higher prices. In case of labour cost it is more predominate than other input cost and in Nihokhu village incurs the highest cost than their counterpart villages spending an amount of ₹ 9863.71 per acre.

Whereas, in Phek district rice farming is mostly in organic farming practices, so the use of fertilizer is totally absent and even the use of pesticides is also very less. Since, it is very much labour intensive the use of inputs apart from labour input is very low among the villages and different farm size. Use

Table 3: Cost of cultivation in WRC under Dimapur district

Singrijan Village

\begin{tabular}{|c|c|c|c|c|c|}
\hline Particulars & $\begin{array}{c}\text { Marginal } \\
\text { Farmers }\end{array}$ & Small farmers & Medium Farmers & Large Farmer & ALL \\
\hline Seeds (₹) & 300 & 300 & 300 & 300 & 300 \\
\hline Fertilizers (₹) & 728 & 743 & 735 & 750 & 739 \\
\hline Farm Yard Manures ₹) & 1260 & 1371 & 1445 & 1350 & 1356 \\
\hline Machine labour (₹) & 2180 & 2132 & 1572 & 1800 & 1921 \\
\hline Bullock labour (₹) & 124 & 128 & 130.9 & 120 & 126 \\
\hline Transportation & 0 & 0 & 0 & 0 & 0 \\
\hline Human labour (₹) & 9,355 & 9,873 & 10,345 & 9,450 & 9756 \\
\hline \multicolumn{6}{|c|}{ Nihoto Village } \\
\hline Seeds (₹) & 300 & 300 & 300 & 300 & 300 \\
\hline Fertilizers (₹) & 655 & 707 & 763.5 & 763 & 722 \\
\hline Farm Yard Manures (₹) & 1,260 & 1,371 & 1,445 & 1,350 & 1356 \\
\hline Machine labour (₹) & 1923 & 1889 & 2112 & 1400 & 1831 \\
\hline Bullock labour (₹) & 124 & 128 & 131 & 120 & 126 \\
\hline Transportation & 333 & 354 & 250 & 312 & 312 \\
\hline Human labour (₹) & 9,355 & 9,873 & 10,345 & 9,450 & 9756 \\
\hline \multicolumn{6}{|c|}{ Nihokhu Village } \\
\hline Seeds (₹) & 300 & 300 & 300 & 300 & 300 \\
\hline Fertilizers $(₹)$ & 692 & 711 & 700 & 730 & 708 \\
\hline Farm Yard Manures (₹) & 950 & 1025 & 1304 & 1350 & 1157 \\
\hline Machine labour (₹) & 2033.33 & 2044 & 2126 & 1900 & 2026 \\
\hline Bullock labour (₹) & 283.33 & 336 & 319 & 317 & 314 \\
\hline Transportation & 190 & 202 & 207 & 190 & 197 \\
\hline Human labour (₹) & 9799.96 & 9789 & 9900 & 9966 & 9864 \\
\hline \multicolumn{6}{|c|}{ Dimapur } \\
\hline Seeds (₹) & 300 & 300 & 300 & 300 & 300 \\
\hline Fertilizers (₹) & 541.81 & 720.46 & 733.07 & 747.77 & 685.77 \\
\hline Farm Yard Manures (₹) & 1156.66 & 1255.94 & 1398.41 & 1350 & 1290.25 \\
\hline Machine labour (₹) & 2045.46 & 2022.01 & 1936.86 & 1700 & 1926.08 \\
\hline Bullock labour (₹) & 177.11 & 197.51 & 193.64 & 185.55 & 188.45 \\
\hline Transportation & 261.66 & 278.1 & 228.75 & 251.25 & 254.94 \\
\hline Human labour (₹) & 9503.32 & 9845.22 & 10196.93 & 9622.21 & 9791.92 \\
\hline
\end{tabular}

Source: Field Survey 2016-17. 
of bullock labour, machine labour and farm yard manures is highest in Chizami village than other counterpart villages, with an average cost ₹ 512.5, ₹ 1830.27 and ₹ 975 respectively. Whereas the use of inputs, like farm yard manures, bullock labour etc. is lowest in Pfutseromi village. Among all three selected villages in Phek district, Pfutseromi village incurs the highest labour cost spending about ₹ $13,489.39$ per acre during the study period of 2016-17.

\section{Average Cost, Average Revenue and Profit/Loss}

Result from table 5 shows that Nihoto village incurs the lowest cost of production with an average of ₹ $13,692.41$, and also earns the highest profit per acre, while Nihokhu village incurs the highest cost with an average cost of $₹ 14,198.74$ and earns the lowest profit per acre among the three villages under Dimapur district. The distribution among the farm size groups, the marginal farmers in Singrijan village receive more profit than their counterparts at an average profit of $₹ 11,625$, indicating that small farm size is more economical to put more effort to yield higher returns than medium and large farm size groups in Nagaland in which limited scope for adoption of advance technology and other psychological factors are practicing at significant level. Similarly, in Nihoto village marginal farmers are doing better than the rest of the farms size, indicating maximum utilization of labour efficiency. Similarly, Nihokhu village the efficiency of small farmers is found to be higher than other farm groups. It incurs an average cost of ₹ 14,391.95 per acre which is one of the lowest costs among the farm size in the village and earns an average revenue of $₹ 26,436$, making a profit of ₹ $11,877.37$. Large

Table 4: Cost of cultivation in WRC under Phek district

Chizami Village

\begin{tabular}{|c|c|c|c|c|c|}
\hline Particulars & Marginal Farmers & Small farmers & Medium Farmers & Large Farmer & ALL \\
\hline Seeds (₹) & 300 & 300 & 300 & 300 & 300 \\
\hline Pesticides (₹) & 100 & 100 & 100 & 100 & 100 \\
\hline Machine labour $(₹)$ & 1875 & 1824 & 2047 & 1575 & 1830.28 \\
\hline Bullock labour (₹) & 550 & 500 & 600 & 400 & 512.5 \\
\hline Human labour (₹) & 12,690 & 12,930 & 12,677 & 12,825 & 12780 \\
\hline Seeds (₹) & 300 & 300 & 300 & 300 & 300 \\
\hline Pesticides (₹) & 100 & 100 & 100 & 100 & 100 \\
\hline Farm Yard Manures (₹) & 600 & 900 & 1,050 & 1,200 & 937.5 \\
\hline Machine labour (₹) & 2119.22 & 1740 & 1710.53 & 1725 & 1823.68 \\
\hline Bullock labour (₹) & 0 & 240 & 462.5 & 450 & 384.16 \\
\hline Pesticides (₹) & 100 & 100 & 100 & 100 & 100 \\
\hline Farm Yard Manures (₹) & 0 & 930 & $1,028.57$ & 900 & 952.85 \\
\hline Machine labour (₹) & 1858.33 & 1691.66 & 1791.17 & 1100 & 1610.29 \\
\hline Bullock labour $(₹)$ & 0 & 560 & 392.85 & 450 & 467.61 \\
\hline Human labour (₹) & 14,287 & 13,180 & 13,139 & 13,350 & 13489 \\
\hline \multicolumn{6}{|c|}{ Phek } \\
\hline Seeds (₹) & 300 & 300 & 300 & 300 & 300 \\
\hline Pesticides (₹) & 100 & 100 & 100 & 100 & 100 \\
\hline Farm Yard Manures (₹) & 712.5 & 910 & 1017.85 & 1100 & 935.08 \\
\hline Machine labour (₹) & 1950.85 & 1751.94 & 1849.55 & 1466.66 & 1754.75 \\
\hline
\end{tabular}

Source: Field Survey 2016-17. 
CD Longkumer and Giribabu

farmers on the other hand are the ones that gets the lowest profit with an average about ₹ 2,740. Small farmers are found to be receive more profit of ₹ $11,167.96$ though the cost of production is found to be the highest of ₹ $14,468.04$ per acre. The study depicts that the overall cost of production in Dimapur District, is about ₹ $14,270.52$ with an average revenue of $₹ 24,136$ and a profit of ₹ $9,864.48$ as per table 5 . The study reveals that marginal farmers obtains better returns than their counterparts while, small farmers stands higher cost of production per acre in selected villages.

Table 5: Average Cost, Average Revenue and Average Profit/Loss of WRC in the three selected villages under Dimapur district (in ₹)

\begin{tabular}{lccc}
\hline \multirow{2}{*}{ FARM TYPE } & \multicolumn{3}{c}{ SINGRIJAN VILLAGE } \\
\cline { 2 - 4 } & AVG & AVG & PROFIT \& \\
& COST & REVENUE & LOSS \\
\hline Marginal Farmer & 13,947 & 25,572 & 11,625 \\
Small Farmer & $14,548.74$ & 25,272 & $10,723.26$ \\
Medium Farmer & $14,529.21$ & 25,596 & $11,066.79$ \\
Large Farmer & 13,770 & 24,240 & $10,470.00$ \\
ALL & $14,198.74$ & 25,170 & $10,971.26$ \\
\hline NIHOTO VILLAGE & & \\
\hline Marginal Farmer & $13,673.09$ & 25,068 & $11,394.91$ \\
Small Farmer & $14,000.79$ & 25,200 & $11,199.21$ \\
Medium Farmer & $13,714.3$ & 24,936 & $11,221.70$ \\
Large Farmer & $13,279.96$ & 23,688 & $10,408.04$ \\
ALL & $13,692.41$ & 24,720 & $11,027.59$ \\
\hline NIHOKHU VILLAGE & & \\
\hline Marginal Farmer & $14,391.95$ & 24,648 & $10,256.05$ \\
Small Farmer & $14,558.63$ & 26,436 & $11,877.37$ \\
Medium Farmer & $14,919.77$ & 21,948 & $7,028.23$ \\
Large Farmer & $14,875.79$ & 17,616 & $2,740.21$ \\
ALL & $14,686.39$ & 22,656 & $7,969.61$ \\
\hline DIMAPUR & & \\
\hline Marginal Farmer & $14,091.19$ & 25,096 & $11,004.81$ \\
Small Farmer & $14,468.04$ & 25,636 & $11,167.96$ \\
Medium Farmer & $14,463.97$ & 24,160 & $9,696.03$ \\
Large Farmer & $14,058.96$ & 21,848 & $7,789.04$ \\
ALL & $14,270.52$ & 24,185 & $9,914.48$ \\
\hline
\end{tabular}

Source: Field survey 2016-17.

Similarly, in Phek district (Table 6), Pufetseromi village incurs the highest cost of production with an average cost of ₹ 16,565.02 and earn the lowest profit with an average of ₹ $2,424.55$. While in Kikruma village the average cost is about $₹ 16,332.5$ and earns a profit of ₹ 2,834.47. On the other hand, Chizami village earns the highest profit among all the three villages with an average profit of ₹ 3,335.94 per acre. Among the farm size groups, in Chizami village marginal farmers incurs the minimum cost of production of ₹ 16,339.97 earns the uppermost profit with an average of ₹ 20,076 and ₹ 3,836.03 respectively. The large farmers on the other hand, earn the second highest cost and profit. The data indicates that marginal farmers more efficient than large farm size groups for their intensive farm operations and effective efforts makes more profitable than their counterpart farmers in all the selected villages. Though the Large farmers are getting the highest revenue but due to the higher cost of production when compared to marginal farmers its profit margin is lower. In Pfutseromi village large farmers incurs the lowest cost of production and also earns the highest profit with an average of $₹ 16,200$ and $₹ 3,548$ respectively.

Table 6: Distribution of Average Cost, Average Revenue and Average Profit/Loss in Phek (in ₹)

\begin{tabular}{cccc}
\hline & \multicolumn{3}{c}{ CHIZAMI VILLAGE } \\
\cline { 2 - 4 } FARM TYPE & AVG & AVG & PROFIT \& \\
& COST & REVENUE & LOSS \\
\hline Marginal Farmer & $16,339.97$ & 20,076 & $3,836.03$ \\
Small Farmer & $16,554.13$ & 19,536 & $3,081.87$ \\
Medium Farmer & $16,699.68$ & 19,656 & $3,056.32$ \\
Large Farmer & 16,400 & 19,932 & $3,632.00$ \\
ALL & $16,498.24$ & 19,800 & $3,335.94$ \\
\hline KIKRUMA VILLAGE & & \\
\hline Marginal Farmer & $15,989.19$ & 19,488 & $3,598.81$ \\
Small Farmer & 16,240 & 17,412 & $1,272.00$ \\
Medium Farmer & $16,263.47$ & 19,500 & $3,336.53$ \\
Large Farmer & $16,837.5$ & 20,140 & $3,402.5$ \\
ALL & $16,332.5$ & 19,140 & $2,834.47$ \\
\hline \multicolumn{4}{c}{ PFUTSEROMI VILLAGE } \\
\hline Marginal Farmer & $16,545.83$ & 18,924 & $2,490.67$ \\
Small Farmer & $16,761.91$ & 19,668 & $3,043.59$ \\
Medium Farmer & $16,752.56$ & 18,804 & $2,261.01$ \\
Large Farmer & 16,200 & 19548 & 3,548 \\
ALL & $16,565.02$ & 19,128 & $2,424.55$ \\
\hline PHEK & \multicolumn{3}{c}{} \\
\hline Marginal Farmer & $16,358.3$ & $19,496.00$ & $3,308.50$ \\
Small Farmer & $16,676.77$ & $18,872.00$ & $2,465.82$ \\
Medium Farmer & $16,665.21$ & $19,320.00$ & $2,884.62$ \\
Large Farmer & $16,545.81$ & $19,873.33$ & $3,527.5$ \\
ALL & $16,561.47$ & $19,356.00$ & $2,864.98$ \\
\hline
\end{tabular}

Source: Field survey 2016-17. 
The study reveals that marginal and large farmers have the highest allocative and technical efficiency among farm size groups. Large farmers make the highest profit in Phek district with an average profit of ₹ 3,527.5, followed by marginal farmers ₹ 3308.50. The average cost of production under Phek district is ₹ $16,561.47$ per acre and its average revenue is $₹ 19,356$ and they obtain profit on an average of ₹ $2,864.98$. The data shows that small farmers incurs the highest cost on production with an average of ₹ $16,676.77$ and large farmers earn the highest revenue with an average of $₹ 19,873.33$ per acre. But on an overall the highest profit is made by marginal farmers with an average of ₹ 3,308.50 than their counterpart of small and medium farmers.

\section{Factor Determinants: Regression Analysis}

\section{Model Specification}

$Y=\alpha+\beta_{1} X_{1}+\beta_{2} X_{2}+\beta_{3} X_{3}+\beta_{4} X_{4}+\beta_{5} X_{5}+\beta_{6} X_{6}+\beta_{7} X_{7}+$ $\beta_{8} X_{8}+\beta_{9} X_{9}+\beta_{10} X_{10}+\beta_{11} X_{11}+\beta_{12} X_{12}+\mu$

Where,

$\mathrm{Y}=$ Output in $(₹)$ (Total production multiplied by price), $\alpha=$ Constant, $X_{1}=$ Farm Size (₹), $X_{2}=$ Household Age (Years), $X_{3}=$ Household Education (Literate $=0$, Illiterate $=1), X_{4}=$ Family Income $(₹), X_{5}=$ Household Assets (₹), $X_{6}=$ Cost on Pesticides (₹), $X_{7}=$ Seed Cost $(₹), X_{8}=$ Fertilizer Cost $(₹), X_{9}=$ Manure Cost (₹), $X_{10}=$ Indebtedness (₹), $X_{11}=$ Technological (₹), $X_{12}=$ Labour Cost (₹), $\mu$ Error Term.

Table 7 shows the regression analysis of selected villages in Dimapur district and it indicates that all the variables are showing expected signs except seed cost in Singrijan village. The explanatory variables in Singrijan village shows that the coefficient of farm size is statistically significant at 1 percent level and it indicates that for every 1 percent increase in farm size leads to an increase in productivity by 0.095 times.

Similarly, the coefficient of educational level of, family income, and technological cost shows a positive and statistically significant at 5 percent level. On contrary to that, the coefficient of fertilizer cost shows a negative and statistically significant at 5 percent level. While the other variables such as manure cost, indebtedness and labour cost shows a positive association with dependent variable and found to be statistically insignificant.
Table 7: Factor determining Rice Production in Dimapur District: Regression Analysis

\begin{tabular}{|c|c|c|c|c|c|}
\hline S1. No. & Coefficient & Singrijan & Nihoto & Nihokhu & Dimapur \\
\hline 1 & Constant & 2.564 & 4.454 & 3.423 & 3.365 \\
\hline 2 & Farm Size & $\begin{array}{c}0.095 \\
(10.95)^{*}\end{array}$ & $\begin{array}{c}0.109 \\
(8.13)^{*}\end{array}$ & $\begin{array}{c}0.111 \\
(8.16)^{*}\end{array}$ & $\begin{array}{c}0.073 \\
(12.44)^{*}\end{array}$ \\
\hline 3 & $\begin{array}{l}\text { Household } \\
\text { Age }\end{array}$ & $\begin{array}{l}-0.095 \\
(0.75)\end{array}$ & $\begin{array}{l}-0.017 \\
(0.12)\end{array}$ & $\begin{array}{l}-0.019 \\
(0.14)\end{array}$ & $\begin{array}{l}-0.066 \\
(0.70)\end{array}$ \\
\hline 4 & $\begin{array}{l}\text { Household } \\
\text { Education }\end{array}$ & $\begin{array}{c}0.035 \\
(2.14)^{* *}\end{array}$ & $\begin{array}{l}-0.027 \\
(0.78)\end{array}$ & $\begin{array}{c}-0.037 \\
(2.02)^{* *}\end{array}$ & $\begin{array}{c}-0.035 \\
(2.55)^{* *}\end{array}$ \\
\hline 5 & $\begin{array}{l}\text { Family } \\
\text { Income }\end{array}$ & $\begin{array}{c}0.129 \\
(2.23)^{* *}\end{array}$ & $\begin{array}{l}-0.142 \\
(2.56)^{*}\end{array}$ & $\begin{array}{l}-0.144 \\
(2.58)^{*}\end{array}$ & $\begin{array}{l}-0.005 \\
(0.08)\end{array}$ \\
\hline 6 & $\begin{array}{l}\text { Household } \\
\text { Assets }\end{array}$ & $\begin{array}{l}-0.051 \\
(0.81)\end{array}$ & $\begin{array}{c}0.155 \\
(2.87)^{*}\end{array}$ & $\begin{array}{c}0.146 \\
(2.73)^{*}\end{array}$ & $\begin{array}{l}0.042 \\
(2.96)^{*}\end{array}$ \\
\hline 7 & $\begin{array}{l}\text { Cost on } \\
\text { Pesticides }\end{array}$ & $\begin{array}{l}-0.085 \\
(0.78)\end{array}$ & $\begin{array}{l}-0.038 \\
(0.44)\end{array}$ & $\begin{array}{l}-0.042 \\
(0.48)\end{array}$ & $\begin{array}{c}0.089 \\
(2.39)^{* *}\end{array}$ \\
\hline 8 & Seed Cost & - & $\begin{array}{l}-0.041 \\
(0.22)\end{array}$ & $\begin{array}{l}0.001 \\
(0.01)\end{array}$ & $\begin{array}{l}-0.062 \\
(0.23)\end{array}$ \\
\hline 9 & $\begin{array}{l}\text { Fertilizer } \\
\text { Cost }\end{array}$ & $\begin{array}{c}-0.313 \\
(2.48)^{* *}\end{array}$ & $\begin{array}{l}-0.157 \\
(0.65)\end{array}$ & $\begin{array}{l}-0.191 \\
(0.79)\end{array}$ & $\begin{array}{c}-0.245 \\
(2.50)^{* *}\end{array}$ \\
\hline 10 & Manure Cost & $\begin{array}{l}0.183 \\
(0.91)\end{array}$ & $\begin{array}{l}0.029 \\
(0.12)\end{array}$ & $\begin{array}{l}0.038 \\
(0.16)\end{array}$ & $\begin{array}{l}-0.018 \\
(0.13)\end{array}$ \\
\hline 11 & Indebtedness & $\begin{array}{l}0.023 \\
(0.64)\end{array}$ & $\begin{array}{l}0.055 \\
(1.02)\end{array}$ & $\begin{array}{l}0.053 \\
(0.98)\end{array}$ & $\begin{array}{c}-0.146 \\
(3.05)^{* *}\end{array}$ \\
\hline 12 & $\begin{array}{l}\text { Technological } \\
\text { Cost }\end{array}$ & $\begin{array}{c}0.600 \\
(2.28)^{* *}\end{array}$ & $\begin{array}{l}0.065 \\
(0.42)\end{array}$ & $\begin{array}{l}0.062 \\
(0.41)\end{array}$ & $\begin{array}{l}0.090 \\
(0.54)\end{array}$ \\
\hline 13 & Labour Cost & $\begin{array}{l}0.702 \\
(0.77) \\
\end{array}$ & $\begin{array}{c}1.042 \\
(2.12)^{* *}\end{array}$ & $\begin{array}{l}0.274 \\
(0.93) \\
\end{array}$ & $\begin{array}{l}0.237 \\
(0.76) \\
\end{array}$ \\
\hline $\mathrm{R}^{2}$ & & 0.913 & 0.893 & 0.896 & 0.796 \\
\hline F-Change & & 47.14 & 29.11 & 26.67 & 44.56 \\
\hline $\mathrm{N}$ & & 50 & 50 & 50 & 150 \\
\hline
\end{tabular}

Note: Figures in the parenthesis indicates ' $t$ ' values; *, and ** indicates 1 percent and 5 percent significance.

In case of Nihoto village the coefficient of both the farm size and household assets shows statistically significant at 1 percent level. It indicates that for every 1 percent increase in the level of farm size and household assets productivity increases by 0.109 and 0.155 times respectively. On the other hand the coefficient of family income shows negative and statistically significant at 1 percent level, indicating that the increase in the level of income of the farmers makes them better off and sometimes it results in lowering the famer's efficiency since he has better income to meet his needs and might not give his full ability and might also get carried away to try another business activity. However, the coefficient of labour cost shows a positive and statistically significant at 5 percent level. 
The regression results in Nihokhu village shows the coefficient of farm size and household assets to be statistically significant at 1 percent level, On the contrary farmer's education and family income is associating a negative relation with the dependent variable and is significant at 5 percent level and 1 percent level respectively. Other variables such as seed cost, manure cost, indebtedness, technological cost and labour are also found to be positive but are insignificant. The overall regression analysis of the three villages under Dimapur district indicates that farm size, household assets shows a positive and statistically significant at 1 percent level each. While the coefficient of cost on pesticides shows positive association with dependent variable and statistically significant at 5 percent level.

Table 8: Factor determining Rice Production in Phek District: Regression Analysis

\begin{tabular}{|c|c|c|c|c|c|}
\hline \multicolumn{2}{|c|}{ S1. No. Coefficient } & \multirow{2}{*}{$\begin{array}{c}\text { Pfutseromi } \\
3.383\end{array}$} & \multirow{2}{*}{$\begin{array}{c}\text { Chizami } \\
2.168\end{array}$} & \multirow{2}{*}{$\begin{array}{c}\text { Kikruma } \\
5.418\end{array}$} & \multirow{2}{*}{$\begin{array}{r}\text { Phek } \\
3.568\end{array}$} \\
\hline 1 & Constant & & & & \\
\hline \multirow[t]{2}{*}{2} & Farm Size & 0.191 & 0.215 & 0.214 & 0.206 \\
\hline & & $(15.75)^{*}$ & $(17.21)^{*}$ & $(8.00)^{*}$ & $(22.96)^{*}$ \\
\hline \multirow[t]{2}{*}{3} & Household & 0.104 & 0.013 & 0.132 & 0.063 \\
\hline & Age & $(2.46)^{* *}$ & $(0.18)$ & $(0.75)$ & (1.15) \\
\hline \multirow[t]{2}{*}{4} & Household & -0.004 & 0.005 & -0.000 & 0.001 \\
\hline & Education & $(0.28)$ & $(0.30)$ & $(0.01)$ & $(0.07)$ \\
\hline \multirow[t]{2}{*}{5} & Family & -0.00 & -0.013 & 0.084 & -0.029 \\
\hline & Income & $(0.01)$ & $(0.28)$ & $(2.18)^{* *}$ & $(2.11)^{* *}$ \\
\hline \multirow[t]{2}{*}{6} & Household & -0.028 & -0.019 & 0.009 & 0.031 \\
\hline & Assets & $(0.85)$ & $(0.33)$ & $(0.13)$ & $(2.59)^{*}$ \\
\hline \multirow[t]{2}{*}{7} & Cost on & -0.118 & 0.114 & 0.210 & -0.051 \\
\hline & Pesticides & $(0.86)$ & $(0.82)$ & $(0.59)$ & $(0.61)$ \\
\hline \multirow[t]{2}{*}{8} & Seed Cost & 0.030 & 0.162 & -0.335 & -0.003 \\
\hline & & $(0.46)$ & $(2.03)^{* *}$ & $(0.74)$ & $(0.05)$ \\
\hline \multirow[t]{2}{*}{10} & Manure Cost & 0.024 & 0.063 & -0.013 & 0.017 \\
\hline & & $(0.60)$ & $(0.81)$ & $(0.13)$ & $(0.46)$ \\
\hline \multirow[t]{2}{*}{11} & Indebtedness & 0.009 & 0.048 & 0.040 & -0.003 \\
\hline & & $(0.36)$ & $(2.29)^{* *}$ & $(0.48)$ & $(0.15)$ \\
\hline \multirow[t]{2}{*}{12} & Technological & 0.959 & -0.014 & 0.052 & 0.026 \\
\hline & & $(2.97)^{*}$ & $(0.34)$ & $(0.48)$ & $(0.78)$ \\
\hline \multirow[t]{5}{*}{13} & Labour Cost & 0.150 & 0.372 & -0.299 & 0.114 \\
\hline & & $(0.51)$ & $(0.99)$ & $(0.54)$ & $(0.52)$ \\
\hline & R2 & 0.914 & 0.938 & 0.814 & 0.874 \\
\hline & F-Change & 36.75 & 52.80 & 15.11 & 87.09 \\
\hline & $\mathrm{N}$ & 50 & 50 & 50 & 150 \\
\hline
\end{tabular}

Note: Figures in the parenthesis indicates ' $t$ ' values; *, and ** indicates 1 percent and 5 percent significance.

Similarly, in Phek district, the regression results in table 8 shows that in Pfutseromi village the coefficient of farm size and technological cost are positive and statistically significant at 1 percent level. It indicates that for every 1 percent increase in the farm size production increases by 0.191 times and for every 1 percent increase in technological cost produce 0.959 times additional units of production. On the other hand, the age of household head shows a positive and statistically significant at 5 percent level. In the same way the regression coefficients in Chizami village shows that the farm size,seed cost and indebtedness are positive associated with dependent variable and statistically significant at 1 and 5 per cent respectively. Whereas, The coefficients of farm size and family income in Kikruma village is found to be positive and statistically significant at 1 and 5 percent level.

The overall regression results in Phek district depicts that the coefficient of farm size and household assets to be positive and statistically significant with the dependent variable and statistically significant at 1 percent level. Whereas, the coefficient of family income shows a negative and statistically significant at 5 percent level. It indicates that as family income increases the farmers put less efforts and distracting towards other business activities since farming is more uncertain and varied.

\section{Production Efficiency: Cobb-Douglas Production Function}

The Cobb-Douglas form was developed and tested against statistical evidence by Charles Cobb and Paul Douglas during 1927-1947. Cobb-Douglas production function is a particular functional form of the production function, widely used to represent the technological relationship between the amounts of two or more inputs (particularly physical capital and labor) and the amount of output that can be produced by those inputs.

The result of Cobb-Douglas production of Dimapur district shows in table 9 that capital plays the most important role in production efficiency of rice in Dimapur with statistically at 1 percent level of significance. While in Nihoto village both capital and labour shows expected signs but statistically insignificant whereas, in Nihokhu village both capital and labour are equally important for production efficiency to generate more returns per acre. 
Table 9: Cobb Douglas Production Function of Wet Rice Cultivation (WRC) in Dimapur District

\begin{tabular}{ccccccc}
\hline S1. No. & Variables & Coefficient & Singrijan & Nihoto & Nihokhu & Dimapur \\
\hline 1 & Constant & $\alpha_{0}$ & 2.901 & 16.248 & 2.658 & 11.854 \\
2 & Capital & $\beta_{\mathrm{K}}$ & $-2.165(2.05)^{* *}$ & $-0.657(0.59)$ & $1.693(2.19)^{* *}$ & $-1.171(2.44)^{*}$ \\
3 & Labour & $\beta_{\mathrm{L}}$ & $2.520(1.06)$ & $-2.203(0.91)$ & $-0.910(2.20)^{* *}$ & $-0.582(1.23)$ \\
4 & $\sigma^{2}=\sigma v^{2}+\sigma \mathrm{u}^{2}$ & 0.081 & 0.101 & 0.067 & -0.165 \\
5 & Log Likelihood & -4.298 & 0.376 & 17.524 & -6.482 \\
6 & No of Observation & 50 & 50 & 50 & 150 \\
\hline
\end{tabular}

Note: Figures in the parenthesis indicates ' $t$ ' values; ${ }^{*}$, and ${ }^{* *}$ indicates 1 percent and 5 percent significance.

Table 11: Cobb Douglas Production Function of Wet Terrace Cultivation (WRC) in Phek District

\begin{tabular}{clccccc}
\hline S1. No & Variables & Coefficient & Pfutseromi & Chizami & Kikruma & Phek \\
\hline 1 & Constant & $\alpha_{0}$ & 1.979 & 9.002 & 4.604 & 3.266 \\
2 & Capital & $\beta_{\mathrm{K}}$ & $0.383(0.96)$ & $1.047(3.61)^{*}$ & $1.284(4.07)^{*}$ & $0.862(5.83)^{*}$ \\
3 & Labour & $\beta_{\mathrm{L}}$ & $0.349(0.48)$ & $-2.028(2.07)^{* *}$ & $-1.139(1.28)$ & $-0.411(0.74)$ \\
4 & $\sigma^{2}=\sigma v^{2}+\sigma \mathrm{u}^{2}$ & & 0.026 & 0.042 & 0.040 & 0.037 \\
5 & Log Likelihood & 35.93 & 20.537 & 23.886 & 71.020 \\
6 & No of Observation & 50 & 50 & 50 & 150 \\
\hline
\end{tabular}

In the same way, the results in Phek district shows that capital plays more predominant role than labour and indicates statistically significant at 1 percent significance level. In case of Pfutseromi both labour and capital are showing a positive sign but are statistically insignificant. On contrary to Chizami village that both labour and capital are equally important to make production efficiency of rice cultivation. Whereas, in Kikruma village only capital showing significant at 1 percent level of significance. It is an interesting to note that though the capital shows positive significant in most villages, the labour is also an important determinant for enhancing the production and productivity in all the selected villages both in Dimapur and Phek districts by the farmers reluctant to use high advance technology in their farming activities.

\section{CONCLUSION}

The present study revealsthat the farm activities in Nagaland is more prevailing labour intensive than capital.Wet rice cultivation is found to be more cost effective than wet terrace and received higher revenue. The result from regression analysis shows that the coefficient farm size and household assets to be positive and statistically significant with the dependent variable and is positive and statistically significant at 1 percent level. However, age and education of head of household, manure cost, technological cost, and labour cost shows positive association but is statistically insignificant. The Study reveals under wet rice cultivation in Dimapur district the farmers are more lucrative than their counterparts in Phek practicing terrace farming. Subsidized inputs, farm equipment's, institutional credit and extensive services to the farmers is very much essential for the farmers and the government should come forward to take and affirmative action plan by promoting farming sector through involvement of agriculture scientists from concerned departments and with the setting up of more Rice Research Centers in the State.

\section{REFERENCES}

Abedullah, Shahzad Kouser and Khalid Mushtaq. 2007. Analysis of technical efficiency of rice production in Punjab (Pakistan), 45(2): 231-244.

Altaf Hussain. 2015. "Agricultural Efficiency at Farm Level: a study in Barak Valley Region of Assam" Volume-I, Issue-V, Page No. 49-55. Monthly Research Journal ISSN: Pp.2394-7969.

Bhupat, M., Desai, Anil, C. Shah and Prakash M. Shingi. 1999. "Raising Agricultural Productivity in Gujarat". Economic and Political Weekly, 34(9): 519-521.

Krishnaji, N. 1975. “Inter-Regional Disparities in per Capita Production and Productivity of Foodgrains". Economic and Political Weekly, 10(33/35), Special Number: 1377-85.

Le Quang Long, Phan Van Thoi, Nghiky Oanh and Doan Manh Tuong. 2013. "Study on Economic Efficiency in 


\section{D) Longkumer and Giribabu}

Rice Production of Cuu Long Delta", Cuu Long Delta Rice Research Institute, Thoi Lai, Can Tho, Vietnam. Omonrice 19: $250-260$.

Linh H. Vu 1994. "Efficiency of Rice Farming Households in Vietnam". Bootstrap and Stochastic Frontier Application Preliminary Draft. Department of Applied Economics, University of Minnesota, \#332M, Buford Ave, St Paul, MN 55108

Longshibeni N Kithan. 2014. “Indigenous for of Paddy Cultivation in Terrace and Jhum fields among the Nagas of Nagaland'. International Journal of Scientific and Research Publications, 4(3).

Md Muzharul Islam Akond and Sumanash Dutta. 2013. "Technical Efficiency of Rice Producing Farms: A Case Study of Char-Chapari Areas of Assam". Journal of Economic \& Social Development, 9(1).
Mohandas, K. and Thomas, E.K. 1997. “Economic Analysis of Rice Production in Kuttanad Areas of Kerala". Agricultural Situation India, 43(3): 555-561.

Ninan, K.N. 1992. "Economics of Shifting Cultivation in India". Economic and Political Weekly, 27(13): A2-A6.

Rukuosietuo Kuotsuo, Dibyendu Chatterjee, Bidyut C. Deka, Rakesh Kumar, Merasenla Ao, Konsam Vikramjeet 2014. "Shifting Cultivation: An 'Organic like' farming in Nagaland", Indian Journal of Hill Farming, 27(2): 23-28.

Vaidyanathan, A. 1977. "Performance and Prospects of Crop Production in India". Economic and Political Weekly, 12(33/34), Special Number: 1355-1368.

Venkatareddy Chennareddy. 1967. "Production Efficiency in South Indian Agriculture", Journal of Farm Economics, 49(4): 816-820. 